Portland State University

PDXScholar

TREC Final Reports

Transportation Research and Education Center

(TREC)

10-10-2011

\title{
2010 Transit Oriented Developments Survey
}

Jennifer Dill

Portland State University, jdill@pdx.edu

Follow this and additional works at: https://pdxscholar.library.pdx.edu/trec_reports

Part of the Transportation Commons, Urban Studies Commons, and the Urban Studies and Planning Commons

Let us know how access to this document benefits you.

Recommended Citation

Dill, Jennifer. 2010 Transit Oriented Developments Survey. TREC-11-01. Portland, OR: Transportation Research and Education Center (TREC), 2011. https://doi.org/10.15760/trec.73

This Report is brought to you for free and open access. It has been accepted for inclusion in TREC Final Reports by an authorized administrator of PDXScholar. Please contact us if we can make this document more accessible: pdxscholar@pdx.edu. 


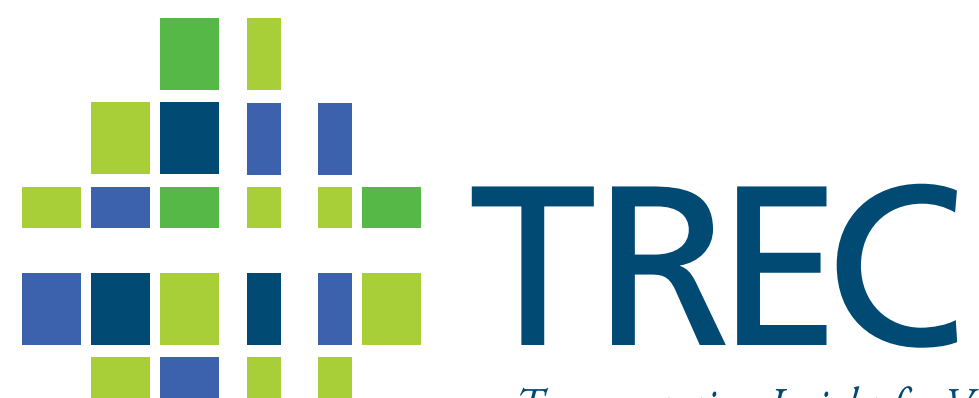

Transportation Insight for Vibrant Communities

FINAL REPORT

2010 Transit Oriented Developments Survey

\section{TREC-11-01 @ October 2011}

TREC is the Transportation Research and Education Center at Portland State University. 


\section{Portland State}

October 10, 2011

TO: $\quad$ Meganne Steele, Metro

FROM: Jennifer Dill, Ph.D.

Center for Transportation Studies

RE: $\quad$ Findings from 2010 TOD Surveys

\section{Introduction}

This report presents results from surveys of residents at several transit-oriented developments (TODs) in Portland, Gresham, Hillsboro, and Happy Valley. The research complements survey work done in 2005 at sites near three MAX stations in Hillsboro and Beaverton (west of downtown) and the Merrick apartments near the Convention Center in Portland, and in 2007 at 11 sites in the eastside of Portland and Gresham. The TODs included in this study are shown in Table 1.

Table 1: TODs included in study

\begin{tabular}{|l|c|c|c|l|}
\hline & $\begin{array}{c}\text { Affordable } \\
\text { units } \\
\text { included? }\end{array}$ & $\begin{array}{c}\text { \# of } \\
\text { units }\end{array}$ & Date built & \multicolumn{1}{|c|}{ MAX Station } \\
\hline Broadway Vantage & Yes & 58 & 2009 & NE 82nd Ave., Portland \\
\hline Russellville Park (senior) & Yes & 283 & 2009 & NE 102nd Ave., Portland \\
\hline $3^{\text {rd } \text { Central }}$ & No & 34 & 2009 & Gresham Central, Gresham \\
\hline Patton Park & Yes & 54 & 2009 & $\begin{array}{l}\text { N Killingsworth St., } \\
\text { Portland }\end{array}$ \\
\hline Villa Capri West & Yes & 20 & 2002 & $\begin{array}{l}\text { Washington/ SE 12th Ave., } \\
\text { Hillsboro }\end{array}$ \\
\hline Nexus & No & 422 & 2007 & $\begin{array}{l}\text { Orenco/ NW 231st Ave, } \\
\text { Hillsboro }\end{array}$ \\
\hline The Beranger & No & 24 & 2006 & Gresham Central, Gresham \\
\hline Town Center Station & Yes & 52 & 2010 & $\begin{array}{l}\text { Clackamas Town Center, } \\
\text { Happy Valley }\end{array}$ \\
\hline
\end{tabular}




\section{Methodology}

To allow comparison across the region, the surveys were conducted in the same manner as in 2005 and 2007 with a very similar survey instrument. The eight-page survey included the following sections:

- Information on your Household. This included questions on household size and number of vehicles.

- Information about up to seven trips taken to and from home on the most recent Tuesday.

- Frequency of walking or bicycling and taking transit to common non-work destinations in good weather

- Changes in daily travel compared to previous residence

- Information on your Place of Work/ School and Commuting.

- Information on Commuting from your Prior Residence

- Information on your Current Place of Residence. This section focused on the importance of various items in selecting their home.

- Information on your Travel Preferences. This section attempts to gauge people's preferences for various modes.

- Typical miles driven in a week and changes in vehicle ownership resulting from characteristics of their current neighborhood.

- Information about you. This section includes standard demographic questions and some questions about mobility impairments.

Each survey packet included two questionnaires (one for each potential adult in the household), a cover letter, and postage-paid return envelope. Respondents were asked to recycle extra forms. The exception was Russellville where we knew how many adults were in each unit and included only the appropriate number of forms. Most of the packets also included a Starbucks card with $\$ 5$ as an incentive. For some of the complexes, the respondents were handed the Starbucks card when they returned the survey to the apartment manager. This method was used at the suggestion of some of the apartment managers. For all of the developments, we conducted a second mailing to non-respondents, and in a handful of cases we did a third mailing, to increase the response rate.

Sample sizes and response rates are in Table 2 . The overall response rate was 35\%, which is higher than in 2005 (29\%) and 2007 (26\%). The inclusion of the $\$ 5$ incentive 
with the survey may be responsible for the higher rate. Response rates for individual developments ranged from $18 \%$ to $49 \%$.

Table 2: Response rates

\begin{tabular}{|l|c|c|c|c|c|}
\hline & $\begin{array}{c}\text { \# units } \\
\text { in survey }\end{array}$ & \# vacant & $\begin{array}{c}\text { \# of units } \\
\text { responding }\end{array}$ & $\begin{array}{c}\text { Response } \\
\text { rate }\end{array}$ & $\begin{array}{c}\text { \# Individual } \\
\text { Surveys } \\
\text { Completed }\end{array}$ \\
\hline 3rd Central & 34 & 0 & 11 & $32 \%$ & 11 \\
\hline Broadway Vantage & 58 & 1 & 12 & $21 \%$ & 15 \\
\hline Nexus & 421 & 43 & 117 & $31 \%$ & 142 \\
\hline Patton Park & 53 & 1 & 24 & $46 \%$ & 30 \\
\hline Russellville Park & 200 & 5 & 11 & $57 \%$ & 111 \\
\hline The Beranger & 18 & 3 & 5 & $33 \%$ & 5 \\
\hline Town Center Station & 52 & 6 & 19 & $41 \%$ & 20 \\
\hline Villa Capri West & 20 & 2 & 4 & $22 \%$ & 4 \\
\hline Total & 856 & 61 & 303 & $38 \%$ overall & 338 \\
\hline
\end{tabular}

aAlso includes guest units not occupied by a regular tenant.

b Each survey packet included two surveys, one for each potential adult resident. Therefore, the total number of surveys completed may be higher than the number of units responding.

\section{Findings}

\section{Trip Generation and Mode Split}

One section of the survey asked about trips made from home for the most recent Tuesday. The intent of this question is to generate a "trip generation" rate for each person. The survey mailings were timed to arrive on Tuesday or Wednesday so as to maximize accuracy in recall. The first trip from home was captured using the three questions shown below. Similar information was collected for up to six additional trips using similar question wording. 
We are interested in learning about how you travel to and from your home. For the next few questions, we are particularly interested in trips you made to and from your home on Tuesday of this week.

If you were out of town on Tuesday of this week, you may answer the questions for another day of the week. Please indicate the day here:

1. On Tuesday of this week, the first time you left your home, where were you going?

$1 \square$ To work

$2 \square$ To school (as a student)

$3 \square$ Shopping, errands, or eating out

$4 \square$ Visiting friends or family

$s \square$ Taking someone else someplace (e.g. child to school)

$6 \square$ Entertainment or exercise

$7 \square$ No particular destination (ex: a jog, stroll, or walking a dog)

$9 \square$ I did not go anywhere on Tuesday. Please skip to Question 7 on page 3.

2. How did you get there?

$1 \square$ Drove alone

$2 \square$ Drove or rode with someone else

$3 \square$ Walked

$4 \square$ Bicycled

$s \square$ MAX

$6 \square$ Trimet bus

$7 \square$ TriMet LIFT service or RideConnection

$\because \square$ Other.

3. When you came back home, how did you get there?

$1 \square$ Drove a vehicle
$2 \square$ Rode with someone else
$3 \square$ Walked
$4 \square$ Bicycled
$5 \square$ MAX
$6 \square$ Trimet bus
$7 \square$ Trimet LIFT service or RideConnection
$8 \square$ Other.

How did you get to the MAX station from home?

${ }_{1} \square$ walk

$2 \square$ drive vehicle $\quad s \square$ bicycle

${ }_{3} \square$ ride as passenger $\quad 6 \square$ other (

How did you get from the MAX station to home?

$1 \square$ walk

$2 \square$ drive vehicle $\quad s \square$ bicycle

${ }_{3} \square$ ride as passenger $\quad 6 \square$ other

The results are shown in Table 3. The first five columns in the table are derived directly from the survey responses. The estimated number of vehicle trips per unit is based upon the total number of single-occupant vehicle (SOV) and carpool trips reported. The carpool trips are adjusted down to account for the carpool trips that were reported by respondents in the same household.

Overall, the residents generated about 2.8 vehicle trips per unit on the weekday examined. This includes trips leaving and coming (to and from) home. The results show wide variation between the TODs. This is due to two factors. First, for TODs with small sample sizes (e.g. Villa Capri, $3^{\text {rd }}$ Central, and The Beranger), the means can be influenced by high or low outliers. Second, the residents of Russellville Park make far fewer trips, which is expected because the vast majority of those respondents do not work. In fact, about one-quarter of the respondents reported not leaving Russellville Park on the reporting day. Therefore, it is most appropriate to look at the bottom row ("All TODs, except Russellville") to estimate the vehicle trip generation rate for TODs that are not limited to older adults - 3.3 trips per day. 
Table 3: Number of trips generated

\begin{tabular}{|c|c|c|c|c|c|c|c|}
\hline & \multicolumn{5}{|c|}{$\begin{array}{l}\text { Average Number of Trips per Respondenta, } \\
\text { One-way (Leaving Home) }\end{array}$} & \multirow{2}{*}{$\begin{array}{l}\text { Estimated } \\
\text { vehicle } \\
\text { round-trips } \\
\text { per unit }\end{array}$} & \multirow[b]{2}{*}{$\mathbf{n}^{\mathbf{b}}$} \\
\hline & $\begin{array}{c}\text { All } \\
\text { modes }\end{array}$ & $\begin{array}{l}\text { Public } \\
\text { Transit }\end{array}$ & Walk & $\begin{array}{l}\text { Drive } \\
\text { Alone }\end{array}$ & Carpool & & \\
\hline Nexus & 1.7 & 0.2 & 0.3 & 0.9 & 0.2 & 3.8 & 142 \\
\hline $\begin{array}{l}\text { Russellville Park } \\
\text { (senior) }\end{array}$ & 1.2 & 0.1 & 0.3 & 0.4 & 0.2 & 1.5 & 104 \\
\hline Patton Park & 2.8 & 0.8 & 0.6 & 0.7 & 0.2 & 2.5 & 30 \\
\hline Town Center Stn. & 2.0 & 0.6 & 0.5 & 0.7 & 0.3 & 2.0 & 20 \\
\hline Broadway Vantage & 3.0 & 0.6 & 0.3 & 1.1 & 0.9 & 5.2 & 15 \\
\hline $3^{\text {rd }}$ Central & 2.1 & 0.0 & 0.4 & 1.5 & 0.0 & 3.8 & 10 \\
\hline The Beranger & 2.0 & 0.0 & 0.2 & 1.4 & 0.4 & 5.5 & 5 \\
\hline Villa Capri West & 3.0 & 0.5 & 2.0 & 0.5 & 0.0 & 1.3 & 4 \\
\hline All TODsc & 1.7 & 0.3 & 0.4 & 0.8 & 0.2 & 2.8 & 330 \\
\hline $\begin{array}{l}\text { All TODs, except } \\
\text { Russellville }\end{array}$ & 2.0 & 0.4 & 0.4 & 0.9 & 0.3 & 3.3 & 226 \\
\hline
\end{tabular}

Notes:

TODs with low overall response numbers are shown in grey. Given the low number of total responses, the averages for these individual TODs should be not be considered representative of the development as a whole.

aThis includes respondents who reported not making any trips on the reporting day.

$\mathrm{b}_{\mathrm{n}}=$ number of individual respondents who reported on their trip-making, including making no trips on the reporting day. 35 respondents reported zero trips for the day, including 26 respondents at Russellville Park.

c This average reflects the travel behavior of all of the respondents combined (i.e. a weighted average), not an average of the individual TODs.

This rate could be compared to the ITE rates or other rates used to estimate vehicle travel generated by a development. The number from the survey will be slightly lower than reality, due to trips generated by non-residents, e.g. non-residents visiting residents, delivery trips, and trips made by project employees. However, these are likely to be a small number of trips. The rate of 3.3 trips per unit is significantly lower than the rate Metro uses from the ITE Trip Generation book (about 6.6 trips per apartment ${ }^{1}$ ) and lower than the rate estimated from the TOD surveys conducted in 2007 (4.7). The difference from the 2007TOD surveys may be due to differences in how the trip generation questions were asked and differences in respondent demographics. A higher share of the 2010 respondents have incomes under $\$ 25,000$ (34\% versus $16 \%$ in 2007) and do not own a vehicle (26\% versus $8 \%$ ). The 2007 surveys included more for-sale

${ }^{1}$ Note that ITE's rate for senior-restricted housing units is 3.23 trips per unit, also about twice the rate estimated for Russellville Park. 
units and complexes without affordable housing units. Other demographics, however, were similar. For example, the average household size for both surveys was 1.6 persons per household.

The differences in income and vehicle ownership may also explain some of the difference between the estimated vehicle trip rate and the ITE rate. In addition to the undercounting of non-resident trips mentioned above, the lower rate may also be due to people underreporting trips. There is no reason to believe that the respondents would systematically underreport (or over-report) their trips on the survey form, but there is no way to know for sure. Respondents might over-report transit trips if they thought that response would be viewed favorably by the researchers or other users of the data. It is not possible to know whether this occurred in this case. Respondents may also forget about trips, which would result in an underestimate. However, it is unlikely that respondents would forget half of their trips, which would be necessary to explain the difference between 3.3 and 6.7.

The difference, then, may be due to increased use of alternative modes, compared to the apartments sampled by ITE. From the trips reported, we estimated the mode split for all trips leaving the TODs (Figure 1). About $60 \%$ of all trips were made in personal vehicles. This is significantly lower than the 2009 National Household Travel Survey (NHTS), where $84 \%$ of all trips were made in personal vehicles ( $87 \%$ of trips made by people living in apartments or condominiums), and the 1994-95 Portland regional activity/ travel survey ( $84 \%$ of trips in private vehicles). In addition, $16 \%$ of the trips were made on either MAX or TriMet buses. Moreover, most of the trips categorized as "other" were forms of transit, including TriMet LIFT and other paratransit-type service and the shuttle bus operated by Russellville Park. These shares of transit use are also higher than found in 2007. 


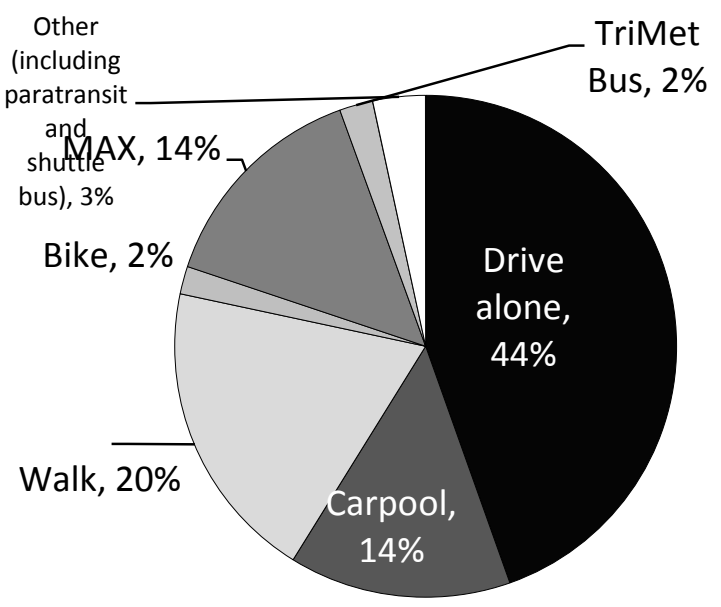

All TODs

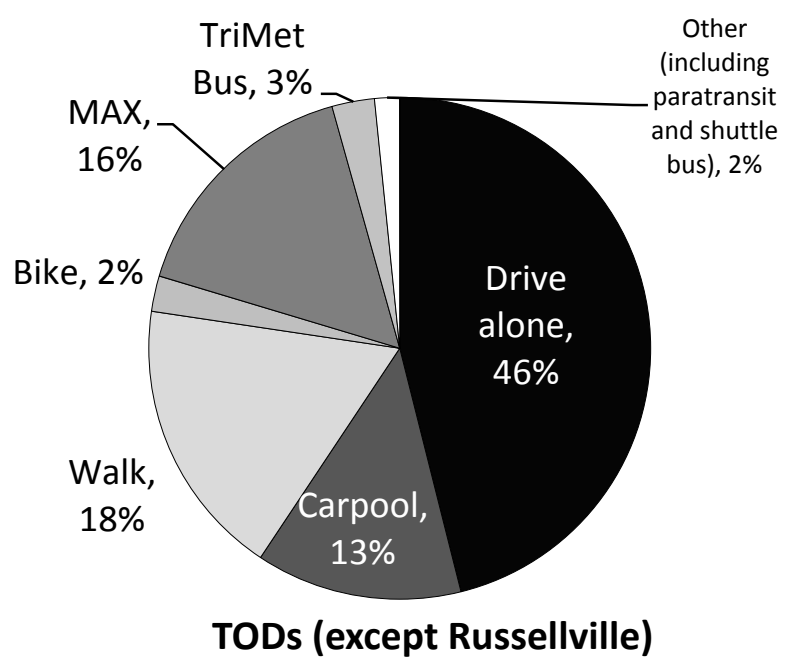

Figure 1: Mode Split for Trips from TODs

Vehicle availability, which is related to income, appears to explain some of these travel patterns. Most of the households had at least one vehicle (Table 4), though the rate of vehicle ownership is lower than found in the previous TOD surveys. Adult respondents living in households with one or more vehicles per person of driving age were far less likely to use transit (Table 5).

Table 4: Vehicle availability

\begin{tabular}{|l|c|}
\hline & $\begin{array}{c}\text { \% of } \\
\text { households }\end{array}$ \\
\hline No vehicles & $26 \%$ \\
\hline One vehicle & $60 \%$ \\
\hline Two vehicles & $12 \%$ \\
\hline Three or more vehicles & $3 \%$ \\
\hline $\mathrm{n}$ & 296 \\
\hline
\end{tabular}


Table 5: Vehicle availability and mode split

\begin{tabular}{|l|c|c|}
\hline & $\begin{array}{c}\text { Less than one } \\
\text { vehicle per } \\
\text { person 16+ }\end{array}$ & $\begin{array}{c}\text { One or more } \\
\text { vehicles per } \\
\text { person 16+ }\end{array}$ \\
\hline$\%$ trips on transit & $30 \%$ & $10 \%$ \\
\hline$\%$ trips by foot/ bike & $27 \%$ & $11 \%$ \\
\hline $\begin{array}{l}\text { \% trips by private } \\
\text { vehicles }\end{array}$ & $42 \%$ & $79 \%$ \\
\hline $\mathrm{n}$ & 137 & 143 \\
\hline
\end{tabular}

Note: Includes all TODs

\section{Commute Mode}

\section{Current Commute Mode}

Another section of the survey asked specifically about commuting to work or school. Overall, over one-quarter of the respondents ${ }^{2}$ used MAX to get to work or school 4-5 days per week and $13 \%$ took the bus that often (Table 6). Over half (57\%) of the respondents drove alone 4- 5 days per week. Considering the combined responses for each respondent, $64 \%$ of the respondents who commuted to work or school $(n=151)$ did so mainly by private vehicle, while $25 \%$ used transit, $7 \%$ walked or biked, and $4 \%$ used multiple non-SOV modes. The survey data for trips made on the reporting day was also used to estimate commute mode split. Due to space constraints, the survey only collected trip purpose for the first two trips made from home. Only $20 \%$ of the respondents who reported trips made more than two trips from home that day. Therefore, it is unlikely that many commute trips were missed by not collecting trip purpose for the third trip and beyond. Of 458 reported trips with trip purpose available, 133 were to work. The mode split for those trips is shown in the last column in Table 6. The commute mode split using this method is similar to that found using the other question, though the share using transit is lower (20\% vs. $25 \%$ ).

The use of transit as a primary commute mode (and on the reporting day) is higher than found throughout the city of Hillsboro (7\%), Gresham (7\%), or Portland (12\%), according to the 2005-09 American Community Survey. Of the respondents who used MAX to commute at least once a week $(n=52), 96 \%$ walked or biked to the station, while only $4 \%$ drove.

2 There were too few commuters at most of the individual TODs to report the shares for each development. 
Table 6: Commute modes, all TODs Surveyed

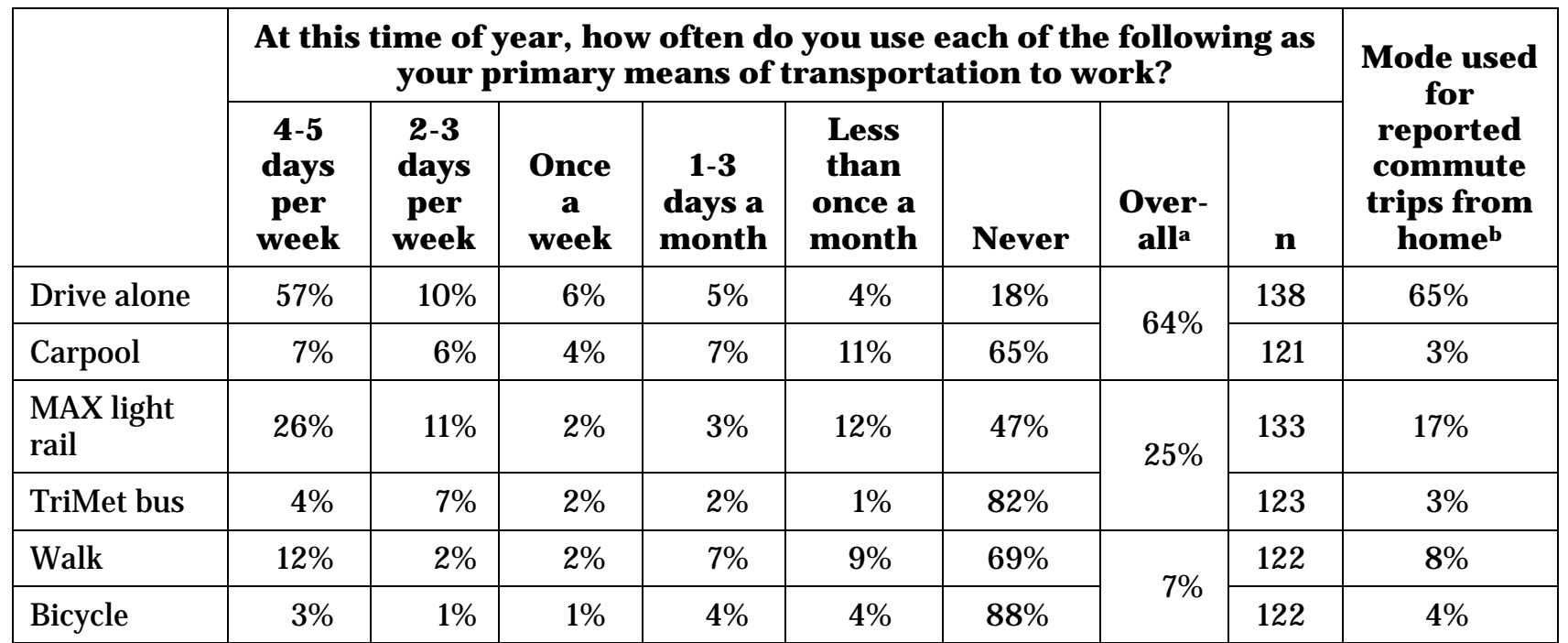

${ }^{a}$ Overall mode was determined based upon the combined responses for each respondent. For example, respondents reporting 4-5 days per week for a mode were assigned that mode. If a respondent indicated 2-3 days per week for two modes, and nothing more frequently, those two modes were used. Therefore, the results are presented with some modes combined. An additional $4 \%$ of respondents used a combination of transit, walking, and bicycling.

$\mathrm{b}$ These data are based upon the trips from home on the reporting day. There were 133 trips from home to work reported.

The price of parking at school or work affects people's commute mode choice. Of the respondents that would have to pay for parking at school or work, only $34 \%$ usually used a private vehicle to get to work (Table 7). In contrast, $76 \%$ of those that do not have to pay to park used a private vehicle. The respondents that would have to pay to park are likely working or going to school downtown or in the Lloyd District, also very convenient locations to reach by transit from many of these TODs.

Table 7: Commute mode and parking cost

\begin{tabular}{|l|c|c|}
\hline & $\begin{array}{c}\text { Would have to } \\
\text { pay to park }\end{array}$ & $\begin{array}{c}\text { Would not } \\
\text { have to pay to } \\
\text { park }\end{array}$ \\
\hline Private vehicle & $34 \%$ & $76 \%$ \\
\hline Transit & $51 \%$ & $15 \%$ \\
\hline Walk/ Bike & $6 \%$ & $9 \%$ \\
\hline Other or combination & $6 \%$ & $3 \%$ \\
\hline $\mathrm{n}$ & 35 & 111 \\
\hline
\end{tabular}

Change in Commute Mode

The survey also asked about the respondent's commute mode at their prior residence.

For both the current and prior commute mode, we categorized people according to their 
most frequent mode. Of the 136 people who reported both commute modes, 18.3\% switched from commuting primarily by private vehicle to transit and/ or walking/ bicycling. However, $12.5 \%$ made the opposite switch, to a private vehicle. Given the sample size $(n=136)$, these percentages are not significantly different from each other, indicating that there was not a significant shift in commute mode from the prior residence. If the sample had been about twice the size, the difference between $18.3 \%$ and $12.5 \%$ would be significant.

Table 8: Changes in Primary Commute Mode from Previous Residence

\begin{tabular}{|l|l|c|}
\hline \multicolumn{1}{|c|}{ Old mode } & \multicolumn{1}{|c|}{ New mode } & $\begin{array}{c}\text { \% of } \\
\text { respondents }\end{array}$ \\
\hline Private vehicle (alone or carpool) & Private vehicle (alone or carpool) & $50.0 \%$ \\
\hline Private vehicle (alone or carpool) & Transit & $13.2 \%$ \\
\hline Private vehicle (alone or carpool) & $\begin{array}{l}\text { Walk/ bike or combination of non-SOV } \\
\text { modes }\end{array}$ & $5.1 \%$ \\
\hline Transit, walk and/ or bike & Private vehicle & $12.5 \%$ \\
\hline Transit, walk and/ or bike & Transit, walk and/ or bike & $15.4 \%$ \\
\hline $\begin{array}{l}\text { Multiple modes (including private and } \\
\text { non-SOV) }\end{array}$ & Transit & $1.5 \%$ \\
\hline $\begin{array}{l}\text { Multiple modes (including private and } \\
\text { non-SOV) }\end{array}$ & Private vehicle & $0.7 \%$ \\
\hline \multicolumn{1}{|c|}{ n=136 } & & \\
\hline
\end{tabular}

\section{Use of alternative modes for non-work trips}

The survey asked people how frequently they walked or biked or used transit from home to get to various non-commute destinations in good weather. A separate question also asked the respondent how many times in the last 30 days they (1) took a walk, jog, or stroll around their neighborhood and (2) took a walk from home to a business or store in their neighborhood.

The results from the transit question are shown in Figure 2 for all of the TODs combined. Respondents were more likely to take transit for shopping, eating out, and going to parks than other non-work purposes. This may reflect the accessibility to downtown Portland and Washington Park (including the zoo) from these TODs via MAX. 


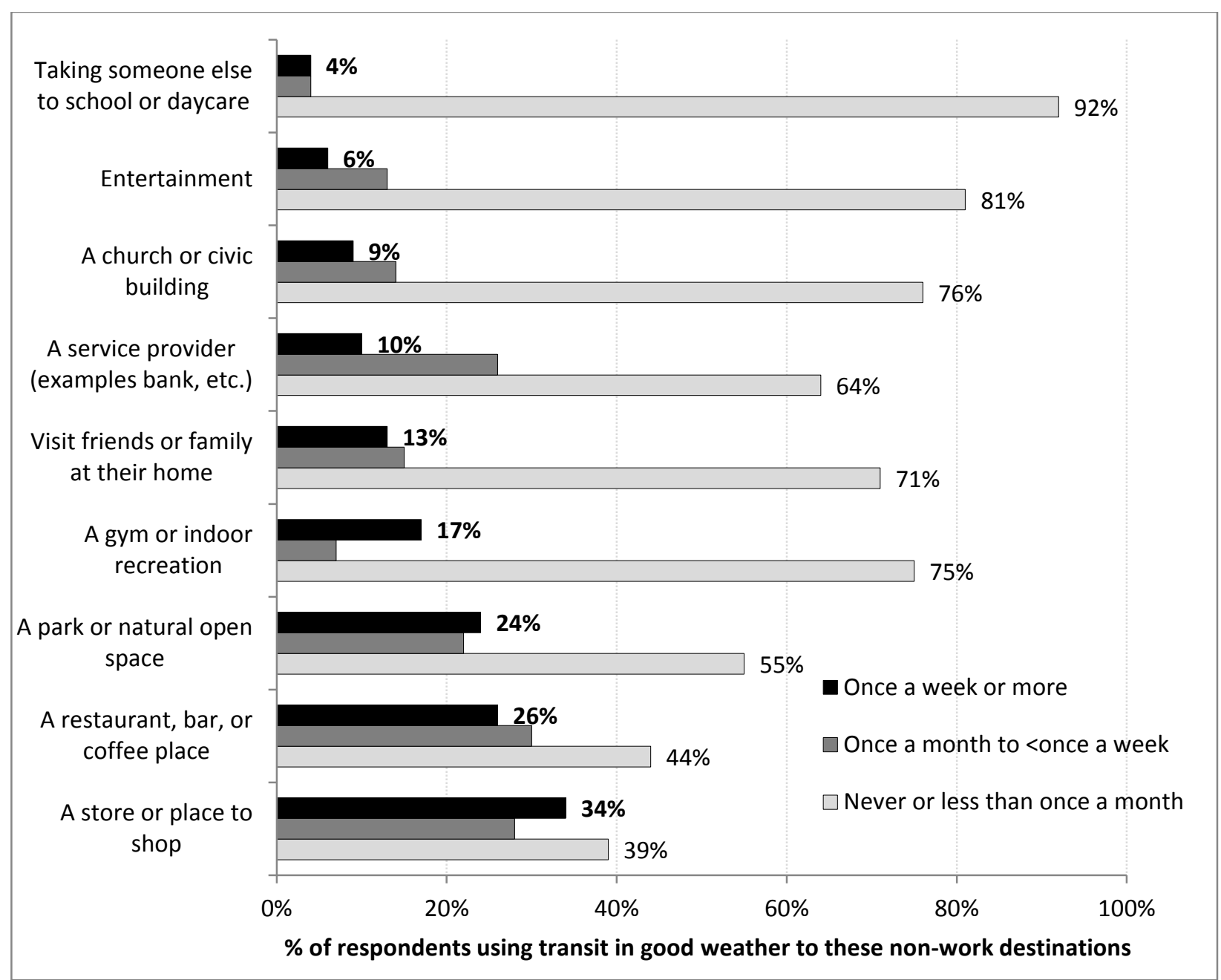

Figure 2: Frequency of taking transit to non-work destinations in good weather

Some of the results for walking and biking, separated by TOD, are shown in Table 9. Over one-third (34\%) of the respondents walked or biked from home to a store once a week or more in good weather, while over one-quarter (26\%) walked or biked to go out to eat. The table is sorted by the average number of walking trips made from home to nearby businesses in the page 30 days. The highest levels of such walking were reported at $3^{\text {rd }}$ Central in Gresham and Patton Park on North Portland. These differences likely reflect the differences in the number of destinations within walking distance in these neighborhoods. 
Table 9: Walking and biking for non-commute purposes

\begin{tabular}{|l|c|c|c|c|c|c|}
\hline & $\begin{array}{c}\text { Walks/bikes } \\
\text { to store once } \\
\text { a week or } \\
\text { more in } \\
\text { good } \\
\text { weather }\end{array}$ & $\begin{array}{c}\text { Walks/bikes } \\
\text { to } \\
\text { restaurant/ } \\
\text { bar/café } \\
\text { once a week } \\
\text { or more in } \\
\text { weod } \\
\text { weather }\end{array}$ & $\begin{array}{c}\text { Walks/ bikes } \\
\text { with no } \\
\text { destination } \\
\text { once a week } \\
\text { or more in } \\
\text { good } \\
\text { weather }\end{array}$ & $\begin{array}{c}\text { Mean \# } \\
\text { walk, jog, or } \\
\text { strolling } \\
\text { trips in } \\
\text { neighborhoo } \\
\text { d in last 30 } \\
\text { days }\end{array}$ & $\begin{array}{c}\text { Mean \# } \\
\text { walking } \\
\text { trips from } \\
\text { home to } \\
\text { business or } \\
\text { store in last } \\
\mathbf{3 0} \text { days }\end{array}$ & n \\
\hline 3rd Central & $43 \%$ & $64 \%$ & $50 \%$ & 13.0 & 11.6 & 11 \\
\hline Patton Park & $30 \%$ & $31 \%$ & $41 \%$ & 12.5 & 10.8 & 27 \\
\hline Nexus & $44 \%$ & $36 \%$ & $38 \%$ & 15.1 & 7.9 & 140 \\
\hline $\begin{array}{l}\text { Broadway } \\
\text { Vantage }\end{array}$ & $50 \%$ & $8 \%$ & $43 \%$ & 6.4 & 7.1 & 13 \\
\hline $\begin{array}{l}\text { Town Center } \\
\text { Station }\end{array}$ & $21 \%$ & $16 \%$ & $26 \%$ & 7.5 & 6.9 & 20 \\
\hline Russellville Park & $16 \%$ & $5 \%$ & $27 \%$ & 9.5 & 1.5 & 89 \\
\hline Total* & $\mathbf{3 4 \%}$ & $\mathbf{2 6 \%}$ & $\mathbf{3 5 \%}$ & $\mathbf{1 2 . 3}$ & $\mathbf{6 . 5}$ & $\mathbf{3 0 9}$ \\
\hline
\end{tabular}

* The total includes results from The Beranger and Villa Capri, which are not reported separately due to small sample size.

\section{Overall Changes in Travel Modes}

Another question asked about how their daily travel compared to their previous residence:

For this question, please think about your current daily travel and your daily travel when you lived at your previous residence not long before you moved. We would like to know about how your travel has changed, for whatever reason. Please answer for your own travel only.

Overall, the TOD residents reported that they are driving less and using transit and walking more than where they used to live. For example, 43\% reported driving a lot less now, $31 \%$ reported using transit a lot more, and $30 \%$ reported walking a lot more. This is in contrast to the changes in commute modes noted above. The difference could be due to four factors. First, they may be making more significant shifts in their non-work travel, which represents a majority of travel. Second, the move to the TOD may have reduced the lengths of their driving trips, i.e. they may make as many driving trips to work, but now those trips are shorter. Third, the increased price of gasoline may have influenced their travel. Without more accurate data about their previous travel patterns, it is impossible to know the magnitude of each of these explanations. Finally, 
respondents may overstate their shifts to non-driving modes. Given the positive social norms associated with walking and taking transit more and driving less, some respondents may have exaggerated their behavioral shifts.

Table 10: Use of modes compared to previous residence

\begin{tabular}{|l|c|c|c|c|c|c|}
\hline & $\begin{array}{c}\text { A lot } \\
\text { less now }\end{array}$ & $\begin{array}{c}\text { A little } \\
\text { less now }\end{array}$ & $\begin{array}{c}\text { About } \\
\text { the } \\
\text { same }\end{array}$ & $\begin{array}{c}\text { A little } \\
\text { more } \\
\text { now }\end{array}$ & $\begin{array}{c}\text { A lot } \\
\text { more } \\
\text { now }\end{array}$ & n \\
\hline $\begin{array}{l}\text { How much do you drive now, } \\
\text { compared to when you lived at your } \\
\text { previous residence? }\end{array}$ & $\mathbf{4 3 \%}$ & $13 \%$ & $\mathbf{2 6 \%}$ & $6 \%$ & $13 \%$ & 215 \\
\hline $\begin{array}{l}\text { How much do you use public transit } \\
\text { (bus or rail) now, compared to when } \\
\text { you lived at your previous residence? }\end{array}$ & $15 \%$ & $6 \%$ & $\mathbf{3 5 \%}$ & $13 \%$ & $\mathbf{3 1 \%}$ & 220 \\
\hline $\begin{array}{l}\text { How much do you walk in your } \\
\text { neighborhood now, compared to when } \\
\text { you lived at your previous residence? }\end{array}$ & $13 \%$ & $8 \%$ & $\mathbf{3 3 \%}$ & $17 \%$ & $\mathbf{3 0 \%}$ & 224 \\
\hline $\begin{array}{l}\text { How much do you ride your bike now, } \\
\text { compared to when you lived at your } \\
\text { previous residence? }\end{array}$ & $\mathbf{3 0 \%}$ & $4 \%$ & $\mathbf{4 9 \%}$ & $8 \%$ & $9 \%$ & 193 \\
\hline
\end{tabular}

Notes: Figures above $25 \%$ highlighted in boldface.

Russellville residents excluded because their move to Russellville may also have coincided with retirement or another life change that could affect travel significantly.

\section{Vehicle Ownership and Use}

To see if there were shifts in vehicle ownership caused by moving to the TOD, the survey asked "Did the number of vehicles available for daily travel by your household change as a result of the characteristics of your current neighborhood?" For about $80 \%$ of the respondents, moving did not impact the number of vehicles in the household (Table 11). However, 38 respondents did indicate that they got rid of a vehicle because of the characteristics of the neighborhood and four got an additional vehicle because of the neighborhood. When the Russellville respondents are excluded 3 , $11 \%$ indicated getting rid of a vehicle because of the neighborhood. Of these, a disproportionate share, about three-quarters, live at The Nexus apartments.

\footnotetext{
3 Since many Russellville respondents are likely to move there when they retire or when they can no longer be as independent as before, they are more likely to get rid of a vehicle.
} 
Table 11: Change in vehicle ownership after moving

\begin{tabular}{|c|c|c|c|}
\hline & \multicolumn{2}{|c|}{$\begin{array}{l}\text { Percent of } \\
\text { respondents }\end{array}$} & \multirow[b]{2}{*}{$\underset{\text { (All) }}{\mathbf{n}}$} \\
\hline & All & $\begin{array}{c}\text { Excluding } \\
\text { Russellville } \\
\text { Park }\end{array}$ & \\
\hline $\begin{array}{l}\text { No, but I/ we are considering getting rid of a vehicle because of the } \\
\text { characteristics of the neighborhood }\end{array}$ & $5 \%$ & $5 \%$ & 15 \\
\hline $\begin{array}{l}\text { No, but I/ we are considering getting another vehicle because of the } \\
\text { characteristics of the neighborhood }\end{array}$ & $2 \%$ & $2 \%$ & 5 \\
\hline No, moving to this place has had no impact on the number of vehicles & $78 \%$ & $81 \%$ & 215 \\
\hline $\begin{array}{l}\text { Yes, I/ we got rid of a vehicle because of the characteristics of the } \\
\text { neighborhood }\end{array}$ & $14 \%$ & $11 \%$ & 38 \\
\hline $\begin{array}{l}\text { Yes, I/ we got an additional vehicle because of the characteristics of the } \\
\text { neighborhood }\end{array}$ & $1 \%$ & $1 \%$ & 4 \\
\hline Total & $100 \%$ & $100 \%$ & 276 \\
\hline $\mathrm{n}$ & 277 & 207 & \\
\hline
\end{tabular}

The survey also asked each person about how many miles they drive in a typical week. For the people with a vehicle in their household, the average number of miles driven per week was 62 and the median was 30, though these numbers are influenced by the large share of respondents who do not drive at all because they do not own a vehicle. Respondents with at least one vehicle drive about 80 miles a week. This would equate to about 4,200 miles per year, which is significantly below national averages. The average apartment dweller in the 2009 NHTS drove about 30 miles per day, or 11,000 miles per year. Some of the difference is likely due to the higher use of alternative modes. However, research indicates that survey respondents are also very likely to underestimate their mileage.

\section{Residential Preferences}

One section of the survey attempted to gauge how important various factors were to the respondents in choosing to live in their current home. The question was:

In this question, we'd like to know what was important to you when you were looking for your current residence. Please indicate how important each of the factors was when you were looking for your current residence on a scale from "not at all important" to "extremely important."

The results are shown in Table 12, ranked from most to least important based on the average score. Living near transit was a priority for most of the residents. About half (48\%) indicated that it was "extremely important" in choosing their current residence and 25\% indicated that it was "somewhat important." 
Table 12: Importance of factors in choosing current residence

\begin{tabular}{|c|c|c|c|}
\hline & Mean & $\begin{array}{c}\text { Std. } \\
\text { Deviation } \\
\end{array}$ & $\mathrm{n}$ \\
\hline Affordable living unit & 3.5 & 0.8 & 311 \\
\hline High quality living unit & 3.4 & 0.7 & 307 \\
\hline Safe neighborhood for walking & 3.2 & 0.9 & 297 \\
\hline Low crime rate within neighborhood & 3.2 & 1.0 & 301 \\
\hline Good public transit service (bus or rail) & 3.1 & 1.1 & 310 \\
\hline Relatively new living unit & 3.1 & 0.9 & 302 \\
\hline Attractive appearance of neighborhood & 3.0 & 0.8 & 302 \\
\hline High level of upkeep in neighborhood & 3.0 & 0.9 & 294 \\
\hline Sidewalks throughout the neighborhood & 3.0 & 1.0 & 302 \\
\hline Good street lighting & 2.9 & 1.0 & 303 \\
\hline Importance of shopping areas within walking distance & 2.9 & 1.0 & 306 \\
\hline Quiet neighborhood & 2.8 & 1.0 & 302 \\
\hline Parks and open spaces nearby & 2.8 & 1.0 & 300 \\
\hline Easy access to downtown & 2.6 & 1.1 & 301 \\
\hline Easy access to the freeway & 2.5 & 1.1 & 301 \\
\hline Lots of off-street parking (garages or driveways) & 2.5 & 1.1 & 301 \\
\hline Easy access to a regional shopping mall & 2.4 & 1.1 & 307 \\
\hline Close to where I worked & 2.4 & 1.3 & 283 \\
\hline Other amenities such as a pool or community center available nearby & 2.3 & 1.1 & 298 \\
\hline Close to friends or family & 2.3 & 1.2 & 287 \\
\hline Lots of people out and about within the neighborhood & 2.3 & 1.0 & 299 \\
\hline Economic level of neighbors similar to my level & 2.3 & 1.0 & 298 \\
\hline Low level of car traffic on neighborhood streets & 2.2 & 1.0 & 295 \\
\hline Diverse neighbors in terms of ethnicity, race, and age & 2.2 & 1.1 & 302 \\
\hline Safe neighborhood for kids to play outdoors & 2.2 & 1.3 & 291 \\
\hline Lots of interaction among neighbors & 2.2 & 1.0 & 299 \\
\hline Variety in housing styles & 2.0 & 1.0 & 301 \\
\hline Good bicycle routes beyond the neighborhood & 1.9 & 1.1 & 293 \\
\hline Big street trees & 1.9 & 0.9 & 299 \\
\hline Living unit on cul-de-sac rather than through street & 1.5 & 0.9 & 289 \\
\hline Good investment potential & 1.5 & 0.9 & 293 \\
\hline High quality K-12 schools & 1.4 & 0.9 & 295 \\
\hline Large front yard & 1.3 & 0.7 & 290 \\
\hline
\end{tabular}

Note: Mean scores on a scale of 1-4, 1=Not at all important, 4=Extremely important 


\section{Travel Preferences}

Some recent research examining the links between land use, urban form, and travel behavior has found that people's attitudes and preferences regarding travel can significantly influence decisions. To help examine this further, the survey included a set of questions about travel preferences:

We'd like to ask about your preferences with respect to daily travel. Please indicate the extent to which you agree or disagree with each of the following statements on a scale from "strongly disagree" to "strongly agree." There are no right and wrong answers; we want only your true opinions.

Respondents ranked a series of statements from "strongly disagree" (1) to "strongly agree" (5). The results are shown in Table 13, sorted based on the statements respondents agreed with most strongly. The results show that these respondents place a high priority on minimizing their travel, by organizing trips, shopping nearby, and using the telephone or internet. While they want to get physical activity and like walking, they also feel that they need a car to do many of the things they like to do. 
Table 13: Travel preferences of TOD residents

\begin{tabular}{|c|c|c|c|}
\hline & Mean & $\begin{array}{l}\text { Std. } \\
\text { Dev. }\end{array}$ & $\mathbf{n}$ \\
\hline I prefer to organize my errands so that I make as few trips as possible & 4.2 & 0.9 & 294 \\
\hline It is important for me to get some physical exercise every day & 4.2 & 0.9 & 294 \\
\hline I like walking & 3.9 & 1.1 & 289 \\
\hline Fuel efficiency is an important factor for me in choosing a vehicle & 3.8 & 1.1 & 282 \\
\hline I need a car to do many of the things I like to do & 3.7 & 1.3 & 287 \\
\hline Traveling by car is safer overall than riding a bicycle & 3.7 & 1.1 & 287 \\
\hline When I need to buy something, I usually prefer to get it at the closest store possible & 3.7 & 1.0 & 295 \\
\hline I often use the telephone or the Internet to avoid having to travel somewhere & 3.5 & 1.1 & 286 \\
\hline I like driving & 3.3 & 1.3 & 286 \\
\hline Public transit can sometimes be easier for me than driving & 3.3 & 1.3 & 284 \\
\hline Walking can sometimes be easier for me than driving & 3.3 & 1.4 & 293 \\
\hline Getting to work without a car is a hassle & 3.2 & 1.4 & 259 \\
\hline I like taking transit & 3.2 & 1.3 & 287 \\
\hline The trip to/ from work is a useful transition between home and work & 3.2 & 1.0 & 259 \\
\hline I prefer to walk rather than drive whenever possible & 3.1 & 1.3 & 286 \\
\hline I try to limit my driving to help improve air quality & 3.1 & 1.1 & 283 \\
\hline The prices of gasoline affects the choices I make about my daily travel & 3.1 & 1.2 & 282 \\
\hline I prefer to take transit rather than drive whenever possible & 3.0 & 1.4 & 284 \\
\hline Vehicles should be taxed on the basis of the amount of pollution they produce & 3.0 & 1.3 & 287 \\
\hline Traveling by car is safer overall than walking & 2.9 & 1.1 & 285 \\
\hline I use my trip to/ from work productively & 2.8 & 1.2 & 258 \\
\hline The only good thing about traveling is arriving at your destination & 2.8 & 1.2 & 287 \\
\hline The region needs to build more highways to reduce traffic congestion & 2.8 & 1.1 & 289 \\
\hline Travel time is generally wasted time & 2.8 & 1.2 & 285 \\
\hline Traveling by car is safer overall than taking transit & 2.8 & 1.1 & 286 \\
\hline Air quality is a major problem in this region & 2.6 & 1.1 & 287 \\
\hline I like riding a bike & 2.6 & 1.4 & 276 \\
\hline We could manage pretty well with one fewer car than we have (or no car) & 2.6 & 1.4 & 289 \\
\hline I am willing to pay a toll or tax to pay for new highways & 2.5 & 1.2 & 285 \\
\hline My household spends too much money on owning and driving our cars & 2.5 & 1.1 & 290 \\
\hline Biking can sometimes be easier for me than driving & 2.4 & 1.3 & 278 \\
\hline I prefer to bike rather than drive whenever possible & 2.2 & 1.3 & 277 \\
\hline I would like to own at least one more car & 2.0 & 1.2 & 289 \\
\hline
\end{tabular}

Note: Mean scores on a scale of 1-5, 1=strongly disagree, $5=$ strongly agree, $3=$ neutral. 


\section{Demographics}

Some of the demographics of the respondents are summarized in Table 14. A majority of the respondents were women, and few of the households had children. Of the nonRussellville Park residents, 48\% were employed full-time, 13\% part-time, and $16 \%$ retired or not working outside of the home. In addition, 5\% were not employed but looking for work.

Some of the respondents indicated travel limitations. Of the Russellville residents, 35\% had a condition that limited their driving, 42\% that limited their walking, and 31\% that limited their transit. For the other respondents, the figures were 5\% (driving), 4\% (walking), and 5\% (transit). The majority of respondents (82\%) had a drivers license; the share was higher (87\%) for non-Russellville residents.

Table 14: Respondent demographics

\begin{tabular}{|l|c|c|c|c|c|}
\hline & $\begin{array}{c}\text { Average \# } \\
\text { people per } \\
\text { household }\end{array}$ & $\begin{array}{c}\text { \% of homes } \\
\text { with people } \\
\text { under 16 }\end{array}$ & $\begin{array}{c}\text { \% of } \\
\text { respondents } \\
\text { over 64 }\end{array}$ & \% female & n \\
\hline 3rd Central & 1.3 & $0 \%$ & $45 \%$ & $73 \%$ & 11 \\
\hline Broadway Vantage & 2.9 & $67 \%$ & $14 \%$ & $93 \%$ & 15 \\
\hline Nexus & 1.8 & $9 \%$ & $4 \%$ & $65 \%$ & 142 \\
\hline Patton Park & 1.9 & $39 \%$ & $3 \%$ & $73 \%$ & 30 \\
\hline Russellville Park & 1.3 & $2 \%$ & $97 \%$ & $67 \%$ & 101 \\
\hline The Beranger & 1.6 & $0 \%$ & $0 \%$ & $80 \%$ & 5 \\
\hline Town Center Station & 1.3 & $21 \%$ & $10 \%$ & $75 \%$ & 20 \\
\hline Villa Capri West & 1.3 & $0 \%$ & $0 \%$ & $100 \%$ & 4 \\
\hline Overalla & 1.6 & $11 \%$ & $35 \%$ & $69 \%$ & 328 \\
\hline
\end{tabular}

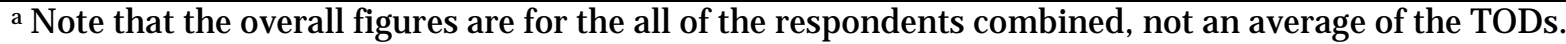

The economic characteristics of the respondents and their households are shown in Table 15 and Table 16. The respondents are generally of low to moderate income, with about one-third falling into the lowest income categories (under $\$ 25,000$ ). On average, the households have far less than one vehicle (0.63) per person of driving age. This is lower than found in the 2007 Eastside TOD surveys, which averaged about 0.8 vehicles per person of driving age. The low vehicle ownership is due, in part to residents of Russellville Park. However, even excluding that TOD, there are only 0.70 vehicles per person of driving age. The residents of Russellville also tend to have higher incomes and education levels. 
Table 15: Household income, education and vehicle availability

\begin{tabular}{|l|c|c|c|c|c|}
\hline & $\begin{array}{c}\text { Median Income } \\
\text { (category) }\end{array}$ & $\begin{array}{c}\text { \% of } \\
\text { respondents } \\
\text { with income } \\
\text { under } \\
\mathbf{\$ 2 5 , 0 0 0}\end{array}$ & $\begin{array}{c}\text { \% of } \\
\text { respondents } \\
\text { with 4-year } \\
\text { college } \\
\text { degree }\end{array}$ & $\begin{array}{c}\text { Average } \\
\text { number of } \\
\text { vehicles per } \\
\text { person 16 or } \\
\text { older }\end{array}$ & $\mathbf{n}$ \\
\hline Russellville Park & $\$ 35,000-49,999$ & $21 \%$ & $67 \%$ & 0.49 & 101 \\
\hline All other TODs & $\$ 35,000-49,999$ & $39 \%$ & $39 \%$ & 0.70 & 220 \\
\hline Total & $\$ 35,000-49,999$ & $34 \%$ & $59 \%$ & 0.63 & 321 \\
\hline
\end{tabular}

\section{Conclusions}

The survey results indicate that a significantly higher share of the TOD residents used transit for commuting than Portland, Hillsboro, and Gresham residents overall (based upon the American Community Survey). The difference is likely due to a combination of factors, including the location of sites near to MAX, income and vehicle ownership, travel preferences of residents, and parking pricing at work and school locations. In addition, it appears that residents of these TODs are generating significantly fewer vehicle trips per unit than assumed by using standard trip generation factors. This difference may be due, in part, to the demographics of the residents, which were generally lower income and less likely to own vehicles compared to the city population and previous TOD surveys. However, it is difficult to disentangle the effects of income from that of the transit access the TOD provides. Good public transit access was an important factor for most of the residents in choosing their current home.

A few key findings have emerged from the analysis done so far:

- Travel patterns of Russellville Park residents are significantly different from those of other TOD residents. In particular, the Russellville Park residents made far fewer trips and a smaller share of their trips on transit. The lower trip generation rate is expected, since the development is for seniors, who are not likely to work. It does mean that when analyzing the potential benefits of future TODs, analysts must consider whether the development is targeted for a certain population.

- Vehicle availability helps explain transit use. TOD residents in households with less than one vehicle per driver were far more likely to use transit. However, the relationship may not be as simple as it appears. Fourteen percent of the respondents indicated that they got rid of a vehicle because of the characteristics of the neighborhood. Therefore, a share of the households with limited vehicle availability 
may have consciously chosen to have fewer vehicles because they could use transit or walk instead, not just because of income.

- Workers at the TODs are commuting regularly on transit at a higher rate (20-25\%) than for all workers in the City of Portland (12\%), Hillsboro (7\%), and Gresham (7\%). This finding reflects, in part, the proximity of the TODs to high-quality transit service (MAX).

- Parking pricing influences commute mode split. Respondents who did not have to pay to park at work or school were far more likely to drive to work.

- Moving to the TOD did not appear to result in a shift to increased transit commuting. While many respondents did change modes after moving to the TOD, there was no statistically significant net change towards transit commuting. The sample size may have limited the ability to detect such a change.

- Respondents indicated that they are driving less and using transit more now compared to their previous residence. If this shift is accurate, it may be due to shifts toward transit for non-commute trips, a shortening of trip distances for both commuting and other purposes, and the influence of increasing gas prices.

- Residents placed a high priority on transit accessibility in choosing their current home. However, they do not necessarily enjoy riding transit more than driving. 